Andrej Stopar*

University of Ljubljana
UDK 811.163.6'342.9:81-115

DOI: 10.4312/linguistica.57.1.293-312

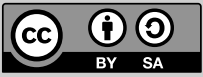

\title{
THE PROSODY OF FOCUS: NON-CONTRASTIVE, CONTRASTIVE AND VERUM FOCUS IN SLOVENIAN, ENGLISH AND RUSSIAN
}

\section{INTRODUCTION AND LITERATURE OVERVIEW}

Most syntax-oriented generative models claim that variation in word order can be accounted for by a set of rules that govern the movement of constituents in the syntactic structure. In such approaches (for instance, Chomsky 1995, et subsq), different types of movement occur that are triggered by the feature-checking requirements ${ }^{1}$ (typically associated with morphosyntactic features) that result in different surface structures. However, since it has been established that word order can also be affected by pragmatic factors, i.e. by the way information is packaged in the sentence (see, for instance, Breul 2004), some authors suggest a separate set of features should be introduced to account for the effects of the so-called information structure (henceforth IS).

This paper follows such an approach, specifically the model developed by a number of Leipzig-based linguists (Junghanns 1997, 2002, 2003; Alter/Junghanns 2002; Junghanns/Zybatow 1997; Zybatow/Junghanns 1998; Zybatow/Mehlhorn 2000), who believe that IS depends on pragmatic elements and that it is realized at the level of the clause. Junghanns, for instance, defines IS as the pragmatically conditioned ordering of constituents based on their communicative value (2002: 10).

The IS-based model encompasses the discourse functions of focus and background, and topic and comment. Focus is related to the information perceived as important by the speaker, while background refers to less important information; topic is what the sentence is about, and comment represents the predication about the topic. Both the focus and topic are marked by features assigned to the relevant constituents in the clause (more in Junghanns 2002; Zybatow/Mehlhorn 2000: 416). According to Zybatow and Mehlhorn, the IS features are "freely assigned to the corresponding constituent in the syntactic tree" (2000: 415), which means that IS "is reflected in intonation and that focussing of syntactic constituents corresponds to a certain pitch contour" (2000: 432). ${ }^{2}$

This paper will examine the link between the assigned IS features and the prosodic characteristics of three types of focus: the non-contrastive focus, the contrastive focus and the verum focus.

* andrej.stopar@ff.uni-lj.si

1 For instance, verb movement in wh-interrogatives can be triggered by a [+QUESTION] feature of root $\mathrm{C}$ that licenses the I-to-C raising in root interrogatives (Ilc/Milojević Sheppard 2002).

2 For an informative syntax-oriented critique of the approach, see Biskup (2011: 68-70). 


\subsection{Non-Contrastive Focus}

The non-contrastive (or 'neutral') focus is realized at the right periphery, ${ }^{3}$ and can be maximal (1a) intermediate (1b) or minimal (1c). Taking into account the pragmatic factors associated with IS, the examples below also include the context questions that illustrate the scope of focus. In all three cases the nucleus is located on the stressed syllable of the final lexical item ( $c f$. Halliday 1967; Wells 2006). ${ }^{4}$

The Slovenian sentence in (1a) demonstrates the maximal non-contrastive focus; the whole sentence represents important information from the speaker's point of view. The feature $[\mathrm{FOC}]$ is assigned to the whole sentence.

(1a) A: Kaj se dogaja? B: [FOC ${ }_{T P}\left[_{T O P} \text { Peter }_{i}\right]_{V P} t_{i}$ potuje v London.]]] $\mathrm{A}$ : What is happening? B: Peter is travelling to London.

The Russian example in (1b) shows intermediate non-contrastive focus, where the focus feature is assigned to the VP.

(1b) A: Čto s Miroslavoj? B: [TOP Miroslava $]_{i}\left[_{F O C}\left[{ }_{V P} t_{i}\right.\right.$ uexala v Jaltu.]]

A: What is going on with Miroslava? B: Miroslava left for Jalta.

(Zybatow/Mehlhorn 2000: 417)

The English sentence in (1c) is an example of the minimal focus. The focus feature is on the DP 'books.'

\section{(1c) A: What does John read? [TOP John ${ }_{i}\left[_{V P} t_{i}\right.$ reads [FOC[DP ${ }_{D}$ books.]]]}

Zybatow and Mehlhorn (2000) observe that in Russian the focus exponent, i.e. the syllable carrying the main accent in the clause, is on the final lexical element, regardless of the scope of focus. They also note that the focus exponent is "pronounced with a greater lengthening than any other syllable in the sentence" (2000: 425). Similar conclusions have been made for English, for which it has also been claimed that the three types of non-contrastive focus presented above are ambiguous when taken out of context (Ladd 1996: 202; Wells 2006: 117).

The pitch on the non-contrastive focus exponent in Russian declarative sentences has been identified as falling (Zybatow/Mehlhorn 2000), while the pattern identified for English (Xu/Xu 2005: 170) shows a rise-fall on the focus exponent in the lower pitch range. In an early study of Slovenian phonetics and phonology, Bezlaj (1939: 97-98) describes the Slovenian sentence intonation as rising at the beginning and falling in the

3 With regard to the clausal structure, it is assumed throughout the paper that the clause consists of three layers of projection, headed by the so-called core functional categories ( $c f$. Chomsky 1998: 15): the $\mathrm{V}$ (erbal) $\mathrm{P}$ (hrase), the $\mathrm{T}$ (ense) $\mathrm{P}$ (hrase), and the $\mathrm{C}$ (omplementizer) $\mathrm{P}$ (hrase). The first two are commonly referred to as the right periphery, and the third one as the left periphery (see Rizzi 1997 for details).

4 In the subsequent sections the term 'focus exponent' is used (in line with Zybatow/Mehlhorn 2000). 
second half of the utterance. According to him, individual words have a melody of their own, but nevertheless remain within the constraints of sentence intonation. Since then, declarative sentences have been similarly described as having a falling or "cadent" pitch (Toporišič 2004: 547-552). Nevertheless, the falling tone on the focus exponent can be interrupted by a rise in the fundamental frequency $\left(\mathrm{F}_{0}\right)$ due to the "intonation of a word with the 'acute' in nuclear position, reflecting the realization of Slovene tonemicity" (Šuštaršič 2005: 52; also see Srebot Rejec 1997: 429-430; Šuštaršič 1995: 100-101; and Komar 2008: 65-66).

Utterances with the non-contrastive focus may also exhibit a rise in the $\mathrm{F}_{0}$, signalling the presence of a topic (see 'John' in (1c) above). Zybatow and Mehlhorn (2000: 425 ) describe the Russian pitch on the topic as starting with a rise in the $F_{0}$, which is followed by a fall on the subsequent syllable. Previous studies on Slovenian place the main accent at the beginning of the utterance (Dobnikar 1996: n.p.; Vitez/Aubergé 1995: 2074), which, we believe, corresponds to the constituents that are assigned the [тор] feature in the Leipzig-based IS model. Dobnikar (1996: n.p.) describes any such accent as a rise in $\mathrm{F}_{0}$ "which differs more than $10 \%$ in $\mathrm{Hz}$ from its vicinity."

\subsection{Contrastive Focus}

Similar to the non-contrastive focus, the contrastive focus emphasizes important information in the sentence. However, contrasted elements also trigger alternative propositions (Rooth 1992, 1996).

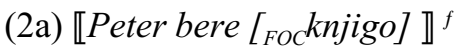

Peter is reading a book.

(2b) $\llbracket\left[\left[_{F O C}\right.\right.$ Peter $]$ is reading a book. $\rrbracket^{f}$

The examples in (2) illustrate the focus semantic value $\llbracket \alpha \rrbracket^{f}$ of the two sentences, which represents "a set of alternatives from which the ordinary semantic value is drawn" (Rooth 1992: 76). In the case of the Slovenian example in (2a), the contrastive focus on the accusative object 'knjigo' triggers the set of propositions of the type 'Peter is reading $y^{\prime}$, where $y$ is every element that may contrast with the ordinary semantic value of 'book,' for instance, a magazine, a journal and similar. In parallel, the contrastively focused subject in the English example ( $2 b$ ) triggers the set of propositions of the type ' $x$ reads a book,' where $x$ can stand for John, Mary, Tom and such like.

The contrastive focus does not have a fixed position in the structure: any constituent in a given string can be contrastively focused by means of a characteristic pitch accent. Zybatow and Mehlhorn (2000: 426-427) show that in Russian there is a "strong rise" on the focus exponent, especially when the focused element appears in sentence-initial and sentence-medial positions. Similarly, the study by Xu and Xu (2005) shows that in English the $\mathrm{F}_{0}$ peak of a word is "consistently higher under a narrow focus than in the neutral-focus sentence" (2005: 167). ${ }^{5}$ The pitch movement is then reversed in the

5 A characteristic example of a pitch contour with the contrastive focus in the sentence-final position can also be observed in Hedberg and Sosa (2008: 111). 
same syllable. For Slovenian, Srebot Rejec (1997: 438-439) notices a wider range of $F_{0}$ frequencies on the sentence-initial contrastive focus exponent: the intonation contour of contrastive focus begins at a lower frequency and reaches a higher maximal than the contour of a non-contrastive constituent in the same position.

Moreover, according to Katz and Selkirk (2011: 806), contrastively focused elements may differ from the non-contrastively marked ones not only with respect to $\mathrm{F}_{0}$ movement, but also with respect to the duration and relative intensity of the focus exponent.

\subsection{Verum Focus}

The verum focus shares two main characteristics with the contrastive focus: (i) it is not limited to a specific syntactic position (other than the positions typically occupied by the verb), and (ii) the relevant focused element (the finite verb) is prosodically marked.

The sentence in (3) is an example from a news report on a Slovenian TV channel.

(3) Kratice krajevnih enot in občinski grbi $\left[_{F O C}\right.$ ostajajo] na novih registrskih tablicah ...

The abbreviations for place names and municipal coats of arms remain on the new licence plates...

(POP TV news report, February 10, 2005)

From a semantic perspective, the verum focus signals contrast between positive and negative meanings. The above example thus triggers a set of two alternatives: 'remain' and 'do not remain.'

The experimental study by Zybatow and Mehlhorn (2000: 428-429) illustrates that the verum focus exponent in Russian exhibits similar prosodic features as the contrastive focus. On the focus exponent, the $\mathrm{F}_{0}$ strongly rises before it starts falling again.

\section{THE STUDY}

The experimental study presented herein measures the fundamental frequencies of Slovenian sentences with the non-contrastive, contrastive and verum focus. The results provide the means for a cross-linguistic comparison of prosodic features of English, Slovenian and Russian. Based on the syntactic/pragmatic model presented in the previous section, the results of the experiment are also used to explore the mapping between syntax and prosody: the findings will show the relevance of prosody for the reconstruction of IS. The experiment mainly builds on the work of Zybatow and Mehlhorn (2000), and is based on the following research question:

How is the assignment of IS features reflected in the prosody of the utterance?

More specifically, this study explores the prosodic differences between the different types of focus structures. Special attention is paid to the changes in pitch contours of the three types of focus, the tone in the syllables bearing the main accent, and the duration of these syllables. The collected data is compared to the findings of similar studies for other languages. 


\subsection{Methodology}

The method used in the study was a controlled experiment. The participants in the experiment were asked to read pre-prepared dialogues that consisted of contextualized instances of the researched structures.

\subsection{Material}

The dialogues included three sentences with the non-contrastive focus (maximal [CP], intermediate [VP], and minimal [PP] scope); three sentences with the contrastive focus on the same constituent situated in various positions in the sentence (initial, medial, and final); and two sentences with the verum focus on the auxiliary verb. The sentences were in the form of dialogues consisting of the target utterance and two to five context sentences. The examples below (4-6) present three dialogues where Speaker A provides the context that elicits a response by Speaker B that contains the utterance with the non-contrastive focus $(4 \mathrm{a}-\mathrm{c})$, contrastive focus (5) and verum focus (6).

(4a) A: Slišim, da nisi mogel oddati diplomske naloge. Kaj se je zgodilo?

I hear you couldn't hand in your diploma thesis. What happened?

$B:$ [FOC Profesor je odšel na morje.]

The professor went to the seaside.

[maximal non-contrastive focus]

(4b) A: Torej si počitnice preživel v knjižnici. Kaj pa tvoj profesor?

So you spent your holidays in the library. What about your professor?

B: Profesor [FOC je odšel na morje.]

The professor went to the seaside.

[intermediate non-contrastive focus]

(4c) A: Danes je predavanje zaradi izleta odpadlo. Morda veš, kam je odšel profesor?

Today the lecture was cancelled because of the excursion. Do you perhaps know where your professor went?

B: Profesor je odšel [FOC $n$ a morje.]

The professor went to the seaside.

[minimal non-contrastive focus]

(5) A: Je Mojca že odpotovala na seminar?

Has Mojca left for the seminar yet?

B: $\left[_{F O C}\right.$ Andreja] je odpotovala na seminar. Mojca ima preveč dela.

Andreja left for the seminar. Mojca is too busy.

[contrastive focus]

(6) A: Jožica je tako trmasta. Spet noče popraviti članka.

Jožica is so stubborn. Once again she refuses to revise the article.

B: Jožica ${ }_{F O C}$ bo] popravila članek. Na tem vztrajam! V nasprotnem primeru ne bom dovolil objave.

Jožica will revise the article. I insist on it. Otherwise I will not allow the publication.

[verum focus] 


\subsection{Participants}

Eleven respondents participated in the experiment. All were female and native speakers of Slovenian, aged between 22 and 29 at the time of the experiment. The group was homogenous with regard to gender to compensate for the different pitch ranges in males and females. The participants were from different regions of Slovenia, but since the dialogues were written in standard Slovenian and the participants were asked to read them using this variety, the potential dialectal influences, aside from tonemicity effects, can be disregarded.

\subsection{Procedure}

The participants were instructed to familiarize themselves with the dialogues and imagine the situations suggested by the context. Then they were asked to read the dialogues. Their performance was recorded and they were allowed to re-read the text if they felt this was necessary. The process typically lasted between 20 and 30 minutes.

\subsection{Equipment}

The recording took place at various locations; however, special attention was paid to ensure acceptable background noise levels. A laptop computer equipped with an external microphone and the Praat software (Boersma 2001; Boersma/Weenink 2005) was used to record the participants. The dialogues were recorded at $48 \mathrm{kHz}$ with a sample rate of 16 bits.

The analysis of the recordings was conducted using Praat. We extracted the sentences relevant for the analysis, plotted their oscillograms, identified the syllable boundaries, and measured the relevant $\mathrm{F}_{0}$ values for each syllable. At least three measurements were taken for each syllable: the initial $F_{0}$ value, the maximal $F_{0}$ value, and the final $\mathrm{F}_{0}$ value. For the syllables carrying the focus exponent of the non-contrastive, contrastive, or verum focus, two additional $\mathrm{F}_{0}$ measurements were taken, located between the initial and maximal, and the maximal and final $\mathrm{F}_{0}$ measurement points. For each point, the values for time (in seconds) and fundamental frequency (in $\mathrm{Hz}$ ) were noted.

\subsection{Statistical analysis}

The collected data was analysed on two levels. Firstly, we measured the distance of the $\mathrm{F}_{0}$ frequency vectors of individual participants from the average $\mathrm{F}_{0}$. Secondly, we tested whether the $\mathrm{F}_{0}$ frequency vectors of individual participants fall into the $90 \%$ confidence interval. Such an analysis was used to exclude any outliers, i.e. speakers whose intonation differed excessively from the average values. The data was also used to create statistically prototypical, interpolated $\mathrm{F}_{0}$ contours of the analysed sentences. Finally, the average $\mathrm{F}_{0}$ contours were used to compare different types of focus structures. 


\section{RESULTS}

Each type of focus is represented in two ways: (i) by a Praat diagram of the speaker who was statistically closest to the average and (ii) by an Excel diagram that represents the average fundamental frequency curve which is based on the averages of the measured coordinates.

\subsection{Non-Contrastive Focus}

The results show the data for sentences with different scopes of non-contrastive focus: maximal, intermediate and minimal.

\subsubsection{Maximal Non-Contrastive Focus}

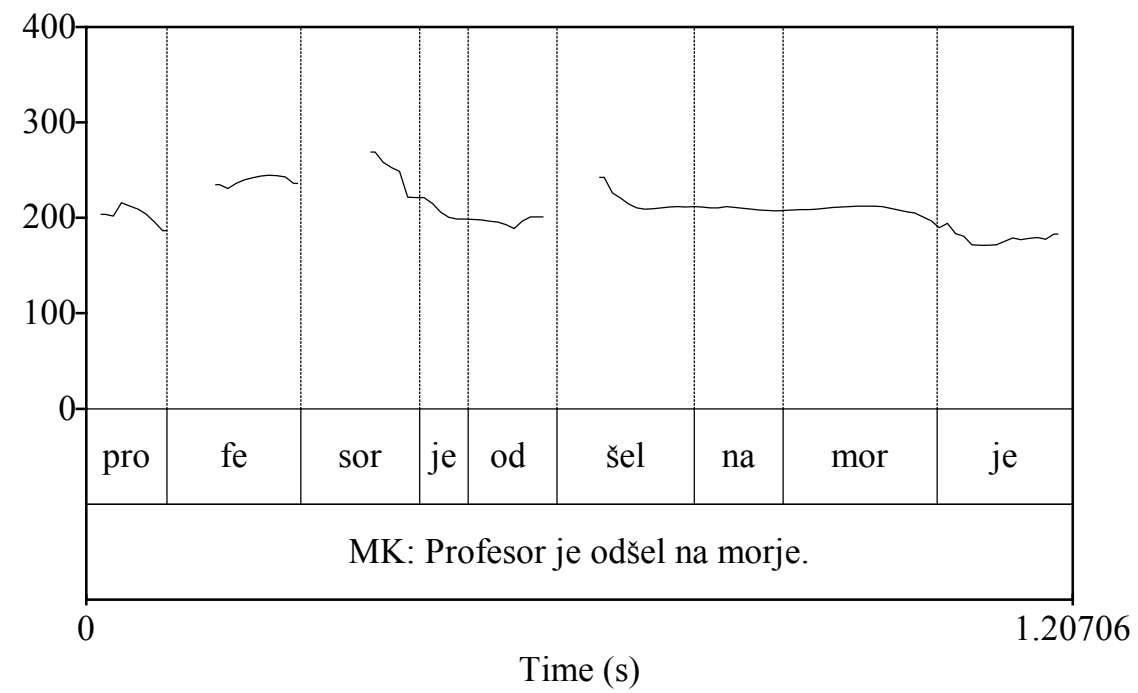

Figure 1: The utterance 'Profesor je odšel na morje' illustrating the maximal non-contrastive focus $^{6}$

The pitch contour of the focus exponent (the syllable mor-) in a maximally focused sentence (Figure 1) starts with a slight rise, which is followed by a gradually descending curve. The fall is slight, but leading towards the lowest pitch in the intonation contour.

6 The initials included before the utterance in this and subsequent Praat figures indicate the individual speaker. 


\subsubsection{Intermediate Non-Contrastive Focus}

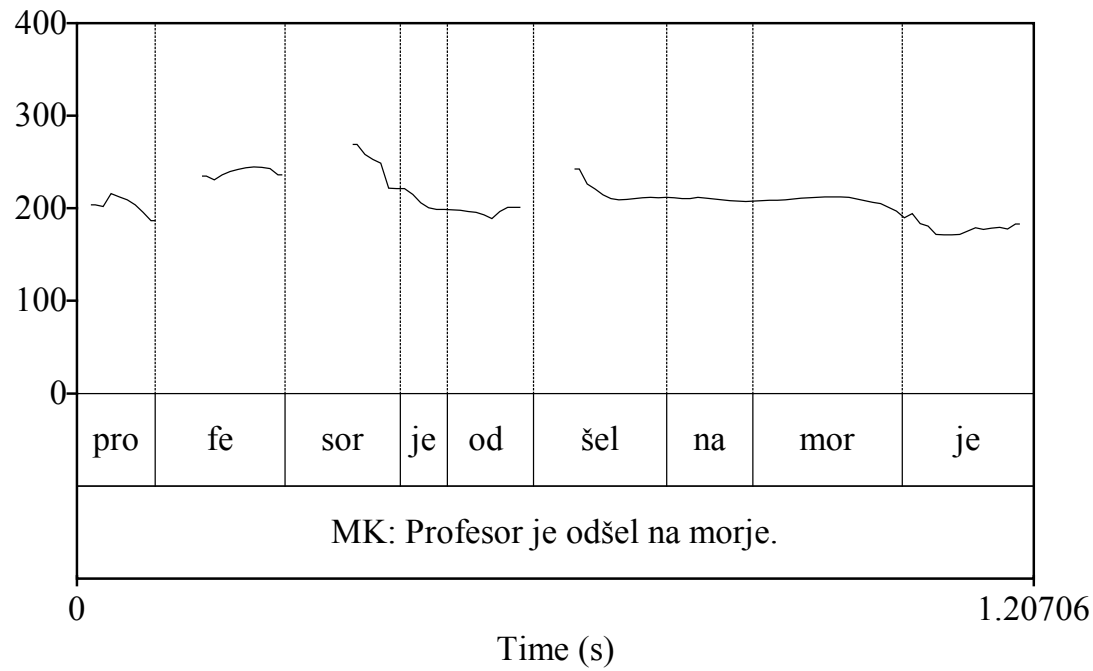

Figure 2: The utterance 'Profesor je odšel na morje' illustrating the intermediate non-contrastive focus

The shape of the intonation contour that was identified for the maximally focused sentence is repeated in Figure 2: after a rise-fall on the focus exponent, the pitch continues to fall towards one of the lowest pitch frequencies in the utterance.

\subsubsection{Minimal Non-Contrastive Focus}

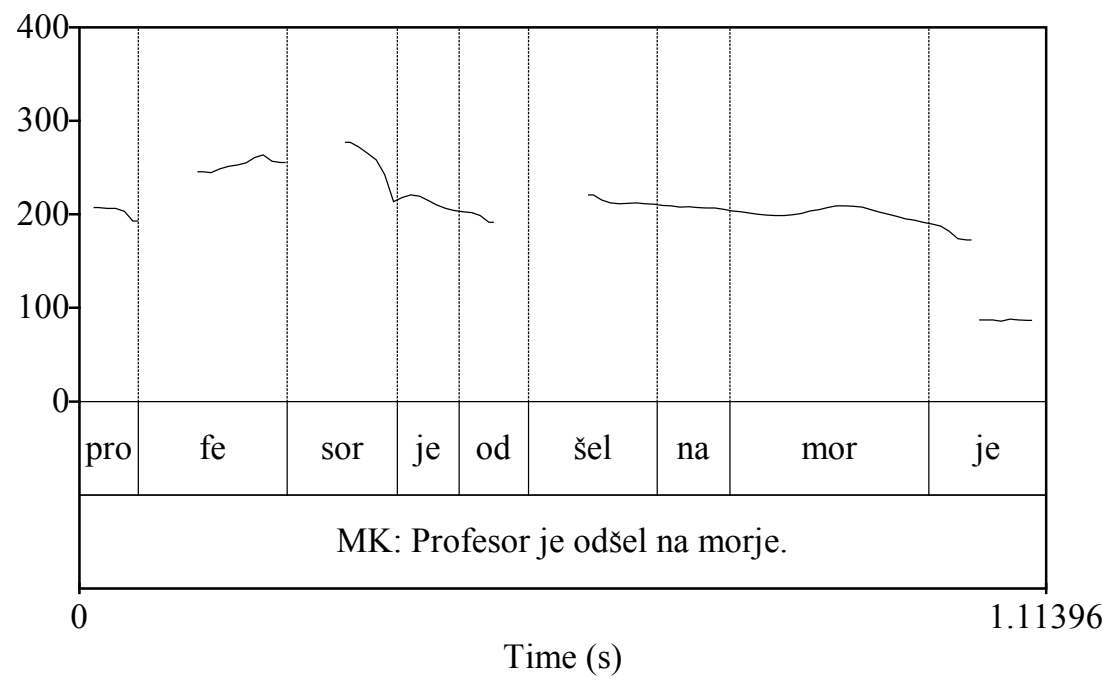

Figure 3: The utterance 'Profesor je odšel na morje' illustrating the minimal non-contrastive focus 
The intonation contour of the minimally focused sentence (Figure 3 ) is similar to the previous examples of utterances with non-contrastive focus. The slight fall that starts on the syllable preceding the focus exponent becomes a rise on the syllable mor-before falling to a low-pitch position.

\subsubsection{Non-Contrastive Focus Types Combined}

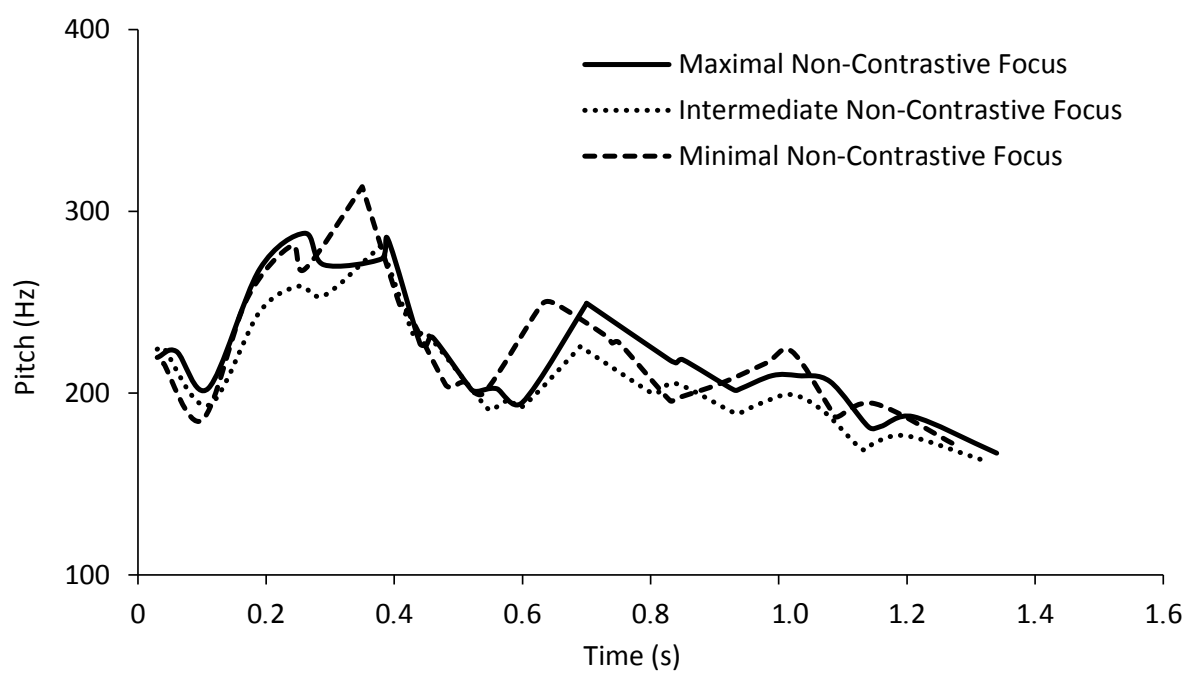

Figure 4: Interpolated intonation contours of the three non-contrastive focus types

Figure 4 presents the averages of nine speakers for maximally and minimally focused utterances, and the average of eight speakers for the utterance with the intermediate non-contrastive focus. The overlay shows that the three contours are difficult to distinguish from one another. The contours proceed in an overall down-trending pattern in the pitch range between 170 and $320 \mathrm{~Hz}$. The potentially topicalized element at the beginning of the utterance ('profesor') shows the highest pitch values of around 300 $\mathrm{Hz}$ after a rise in $\mathrm{F}_{0}$. The focus exponents, on the other hand, exhibit a rise-fall pattern above the 200-hertz range, regardless of the scope of focus.

\subsubsection{Syllable Duration in Sentences with Non-Contrastive Focus}

The syllable carrying the focus exponent in the sentences with the non-contrastive focus is also the longest syllable in the utterance. Figure 5 below shows the comparison between the duration of syllables in one of the utterances with the maximal non-contrastive focus; the focus exponent is marked in black (for the $\mathrm{F}_{0}$ contour of the same speaker $c f$. Figure 1). Similar findings can be observed in sentences with the intermediate and minimal non-contrastive focus. 


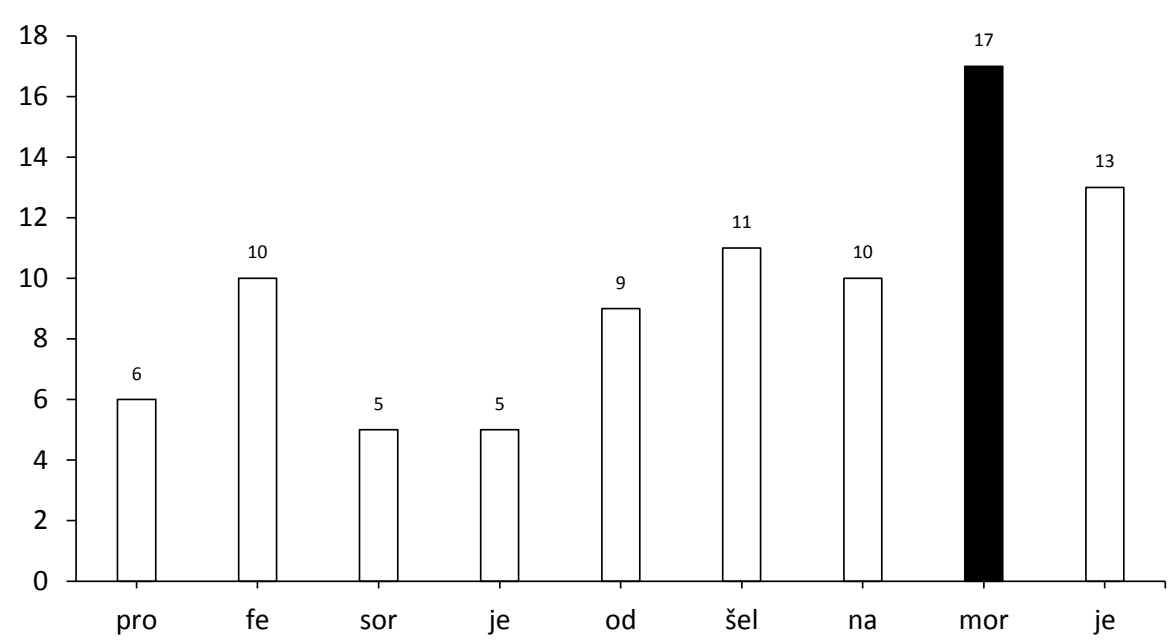

Figure 5: Syllable duration (in msec) in a maximally focused sentence

\subsection{Contrastive Focus}

\subsubsection{Sentence-Initial Contrastive Focus}

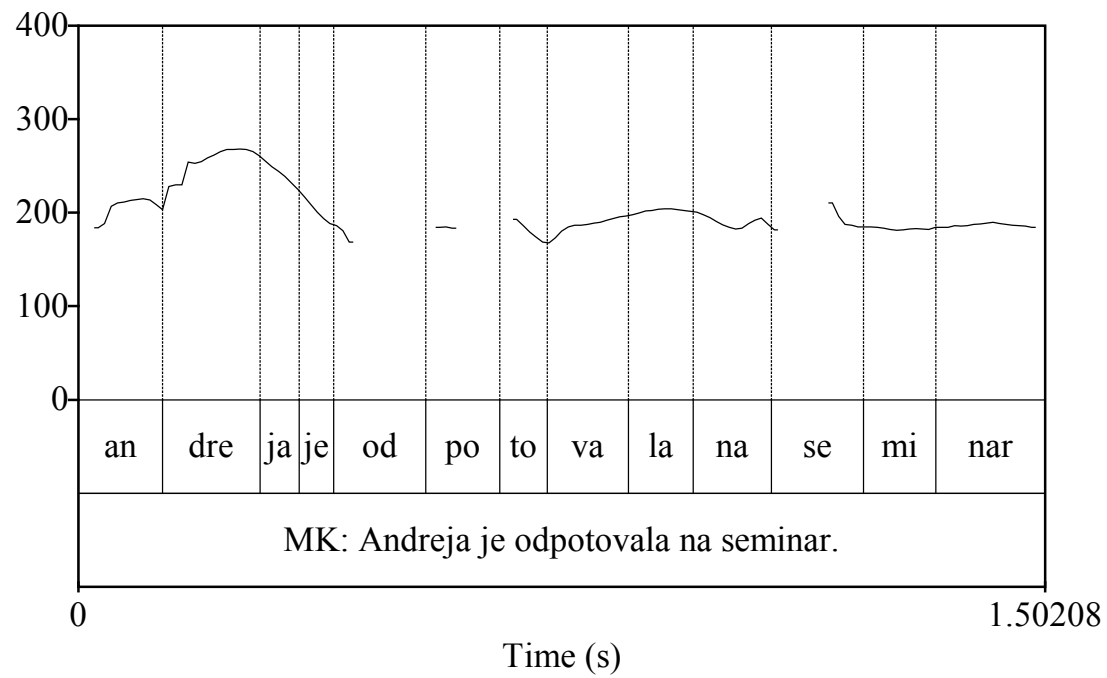

Figure 6: Sentence-initial contrastive focus in the utterance "Andreja je odpotovala na seminar."

Figure 6 shows a noticeable rise on the syllable bearing the contrastive focus accent ( - dre-) situated at the beginning of the intonation contour. The pitch before the focus exponent syllable falls, then rises to reach the highest pitch in the utterance (close to 
$300 \mathrm{~Hz}$ ) before it drops again. The fall continues over the next few syllables and stabilizes in the $200 \mathrm{~Hz}$ range until the end of the utterance.

\subsubsection{Sentence-Medial Contrastive Focus}

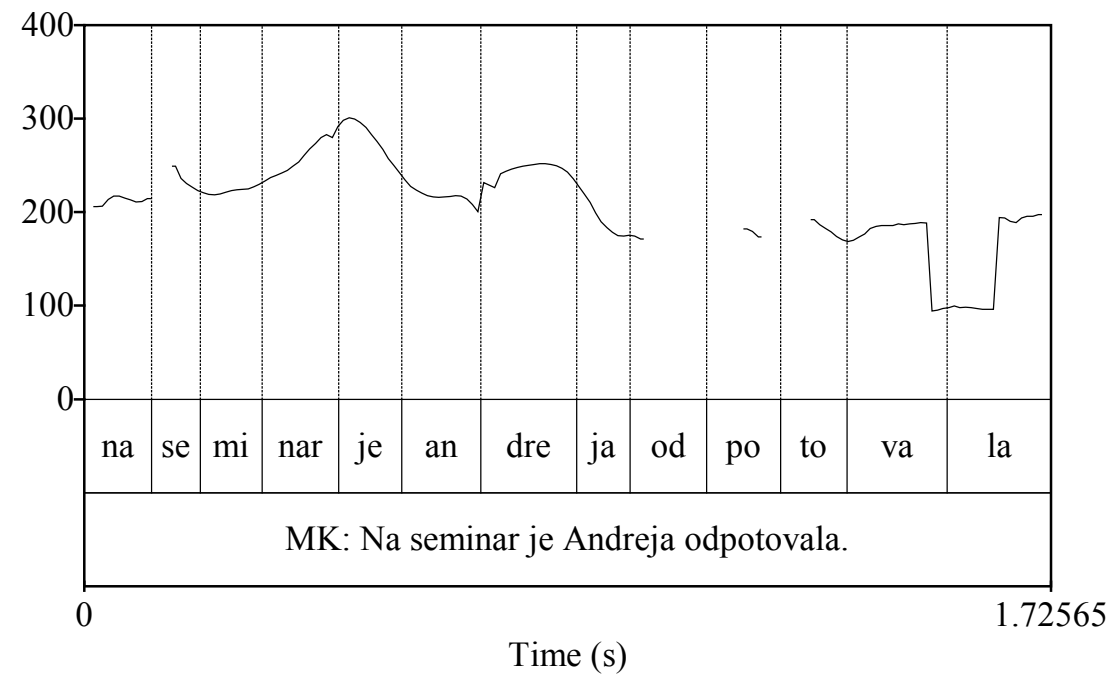

Figure 7: Sentence-medial contrastive focus in the utterance "Na seminar je Andreja odpotovala."

The intonation contour in the utterance with the sentence-medial contrastive focus (Figure 7) is characterised by two rise-falls on the first two constituents. The rise of the contour appears on the stressed syllable of the noun 'seminar,' which is expected since the noun represents the topic of the utterance. The syllable -nar is also the syllable with the highest pitch in the utterance. The second noticeable rise-fall is the one on the contrastive focus exponent, the syllable -dre- in 'Andreja.' The general trend of the contour after the maximal pitch on the topic 'seminar' is falling, with most of it levelling off in the $200 \mathrm{~Hz}$ range. Moreover, the rise-fall on the sentence-medial focus exponent is not as pronounced as the one on the sentence-initial one.

\subsubsection{Sentence-Final Contrastive Focus}

The intonation contour in the above sentence resembles the one in Figure 7. The sentence begins with a rise and a fall on the topicalized constituent, after which the contour levels off in the 200-hertz range. The characteristic rise-fall pattern of the focus exponent is still present on the syllable -dre- (it appears after a fall on the previous syllable); however, these pitch changes are not as pronounced as in the previous examples with the contrastive focus. 


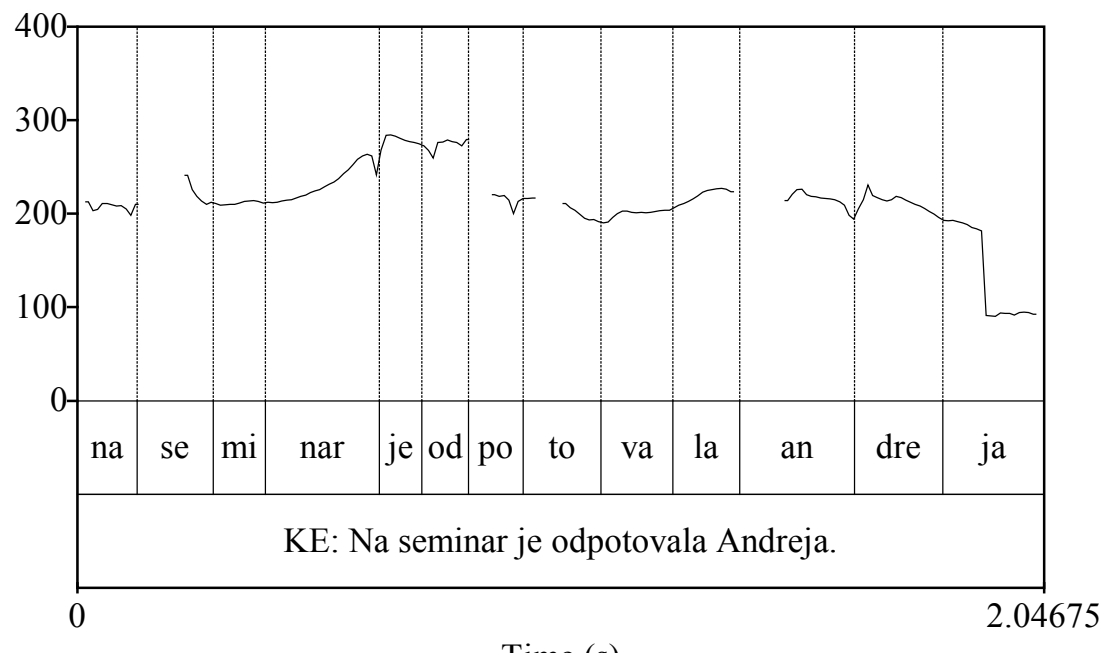

Time (s)

Figure 8: Sentence-final contrastive focus in the utterance "Na seminar je odpotovala Andreja."

\subsubsection{Contrastive Focus Types Combined}

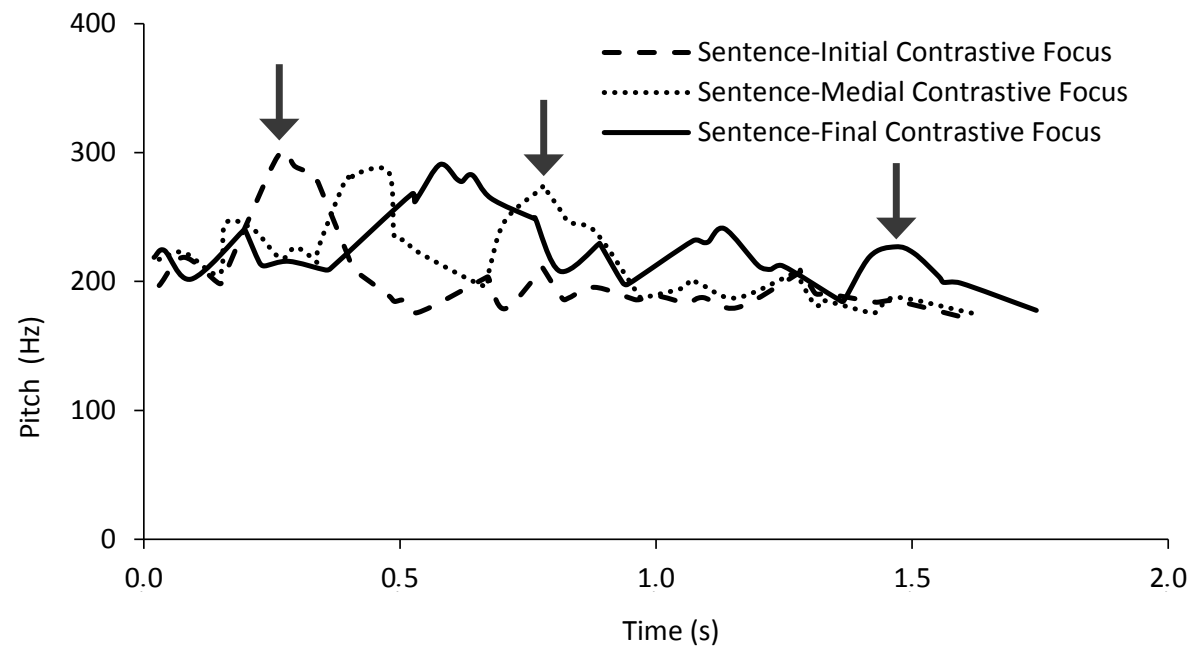

Figure 9: Interpolated contrastive focus contours: the sentence-initial, sentence-medial and sentence-final contrastive focus combined (the focus exponents are marked by arrows)

Figure 9 demonstrates the pitch movement in utterances with the contrastive focus. The average values for the three contours are based on the data for nine speakers for the sentence-initial contrastive focus contour, and eight speakers for the sentence-medial and sentence-final contrastive focus contours. 
The stark differences between the three contours show the role of intonation in contrasting: the constituents carrying the contrastive focus are easily identifiable. The contours share the general pitch range $(170-300 \mathrm{~Hz})$, which is almost identical to the $\mathrm{F}_{0}$ range in the sentences with non-contrastive focus. The contrastive focus exponents are all preceded by a sharp fall in the previous syllable, followed by an even sharper rise and an almost equally sharp fall in the syllable with the focus exponent. The overall downtrend of the pitch contour can still be observed in all three utterances.

The $\mathrm{F}_{0}$ contours of the focus exponents in different sentential positions are similar, although they do not occur in the same pitch range. Figure 10 below illustrates the change in $\mathrm{F}_{0}$ in relation to the position of the contrasted element.

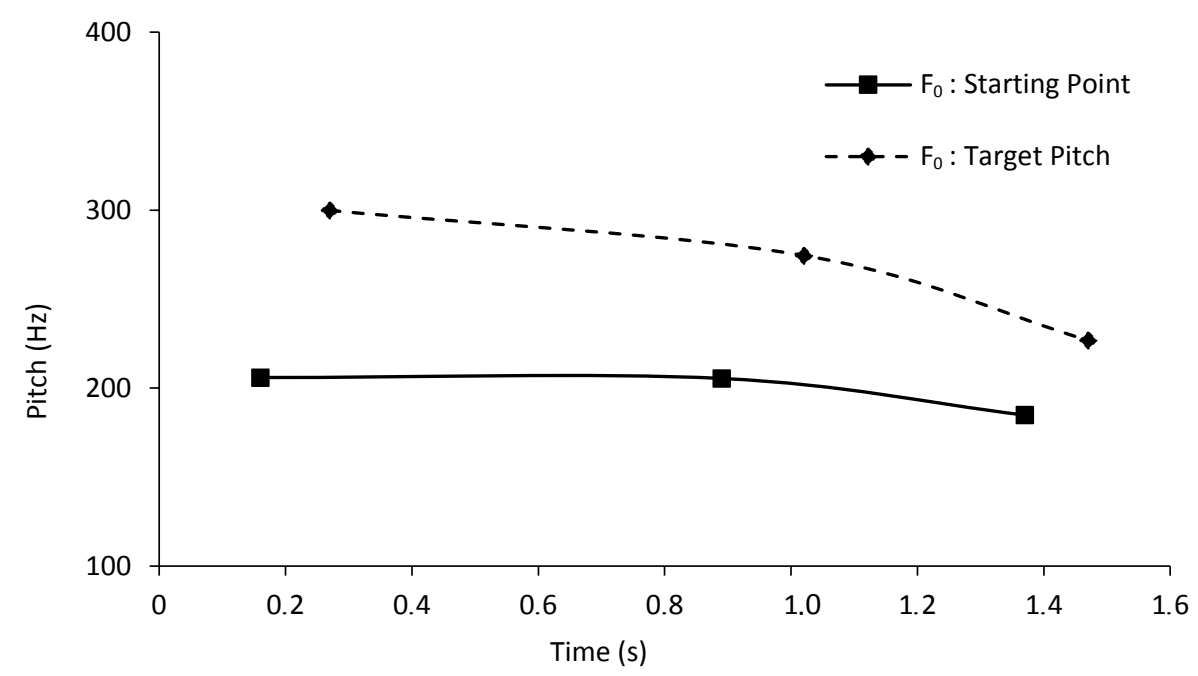

Figure 10: Pitch jumps on the contrastive focus exponents

In the utterances with sentence-initial contrastive focus, the difference in pitch at the beginning of the rise and at the highest point is almost $100 \mathrm{~Hz}$. The distance between these two points diminishes when the focus exponent appears later in the sentence: in the sentence-medial position the jump amounts to about $70 \mathrm{~Hz}$, while in the sentence-final position to around $45 \mathrm{~Hz}$. The three observed pitch rises appear within ten milliseconds.

\subsubsection{Syllable Duration in Sentences with Contrastive Focus}

Figure 11 below compares the duration of syllables in one of the utterances with the contrastive focus in the sentence-initial position. The focus exponent is marked in black (for the $\mathrm{F}_{0}$ contour of the same speaker, $c f$. Figure 6). Similar findings can be observed in sentences with the contrastive focus in sentence-medial and sentence-final positions. 


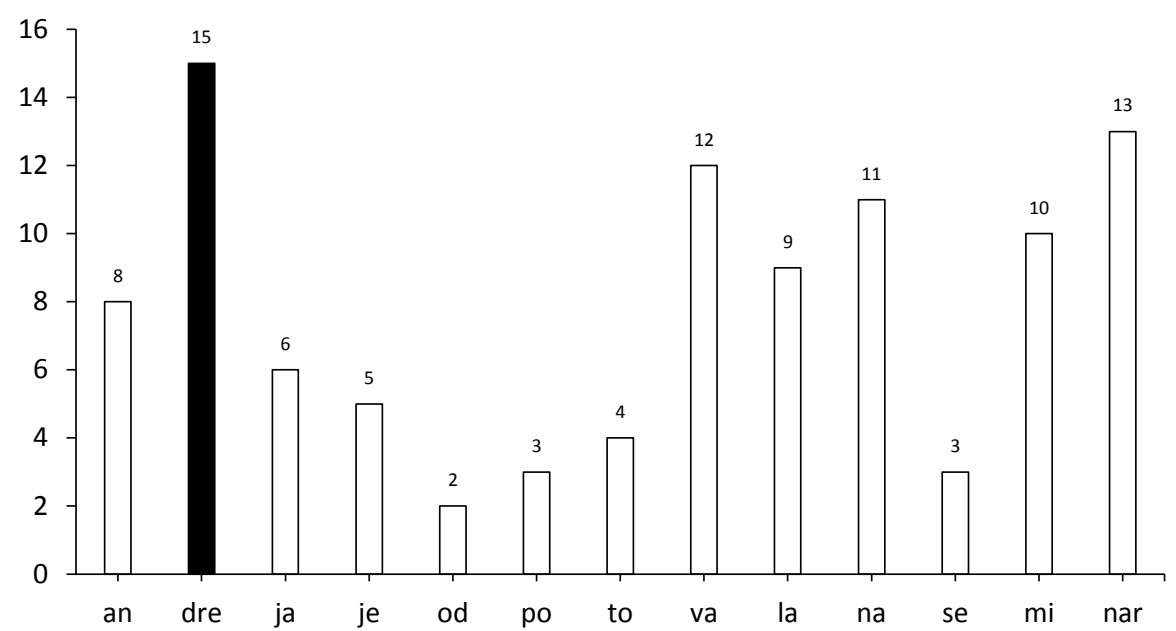

Figure 11: Syllable duration (in msec) in a contrastively focused sentence

\subsection{Verum Focus}

The intonation contour of sentences with the verum focus is similar to the contours for the contrastive focus (see 3.2).

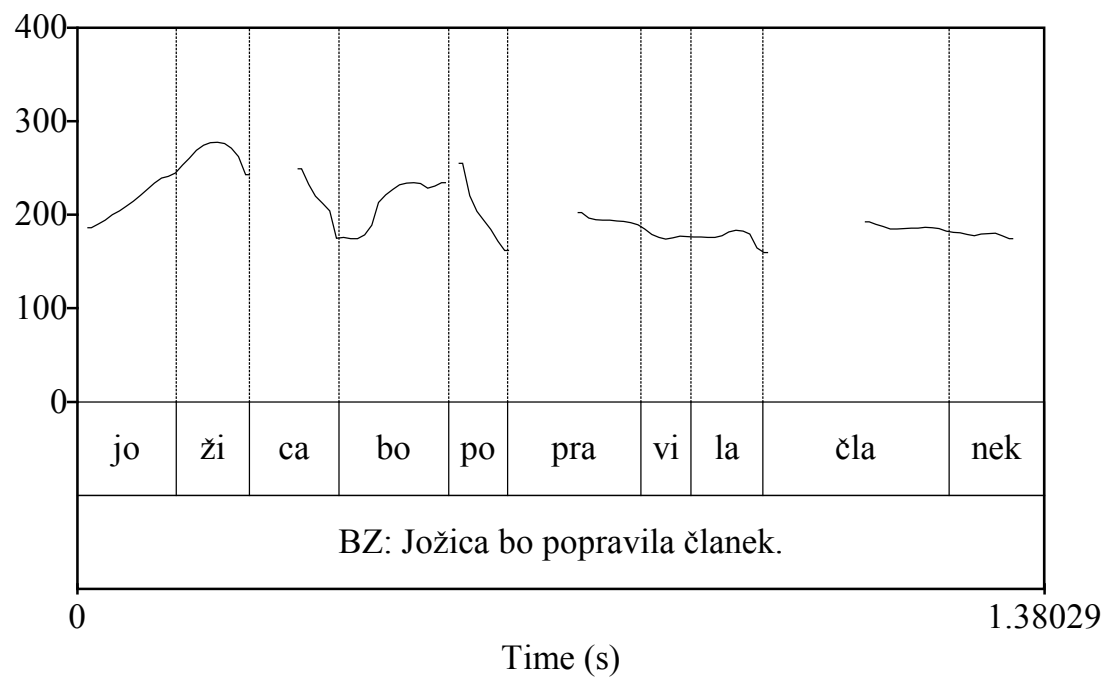

Figure 12: Verum focus in the utterance "Jožica bo popravila članek."

In the sentence in Figure 12, the focus is on the sentence-medial finite verbal form. Before the focus exponent, there is a sharp drop in pitch, which is followed by a similarly noticeable rise (the $\mathrm{F}_{0}$ moves towards the $250 \mathrm{~Hz}$ mark) and a fall that continues 
on the next syllable. The overall down-trend continues until the pitch contour levels off in the 200-hertz range.

The above finding is corroborated by the interpolated pitch contour in Figure 13, which is based on the utterances of seven speakers.

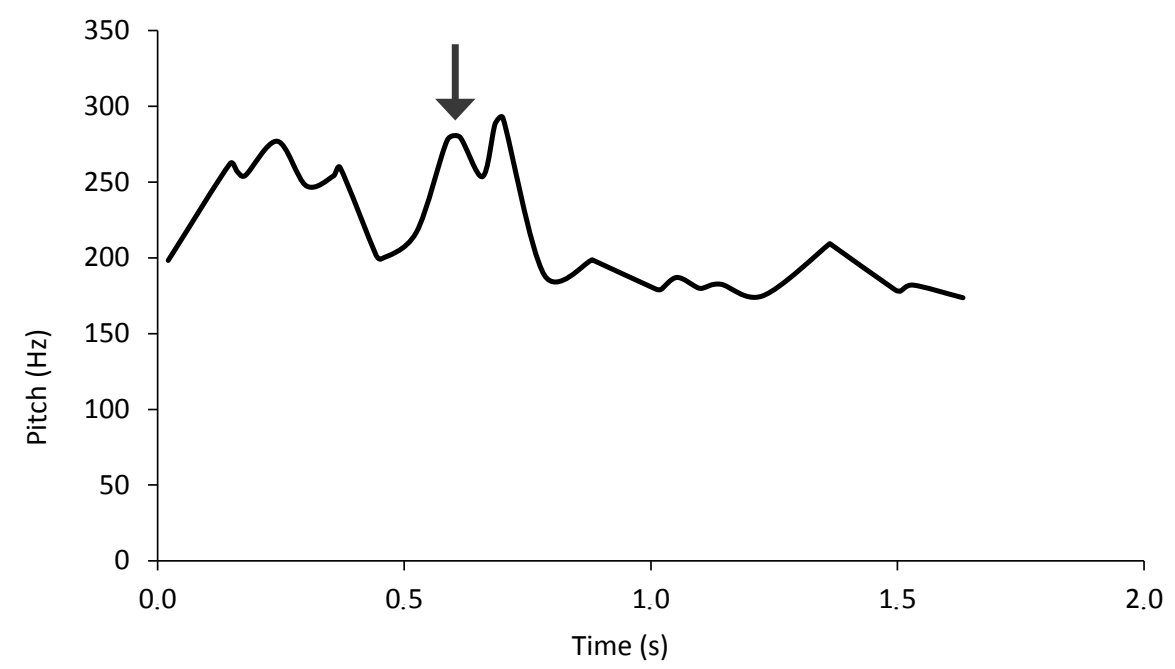

Figure 13: Interpolated verum focus contour ${ }^{7}$

With regard to duration, the sentences with verum focus do not differ from the previous focus types, see Figure 14.

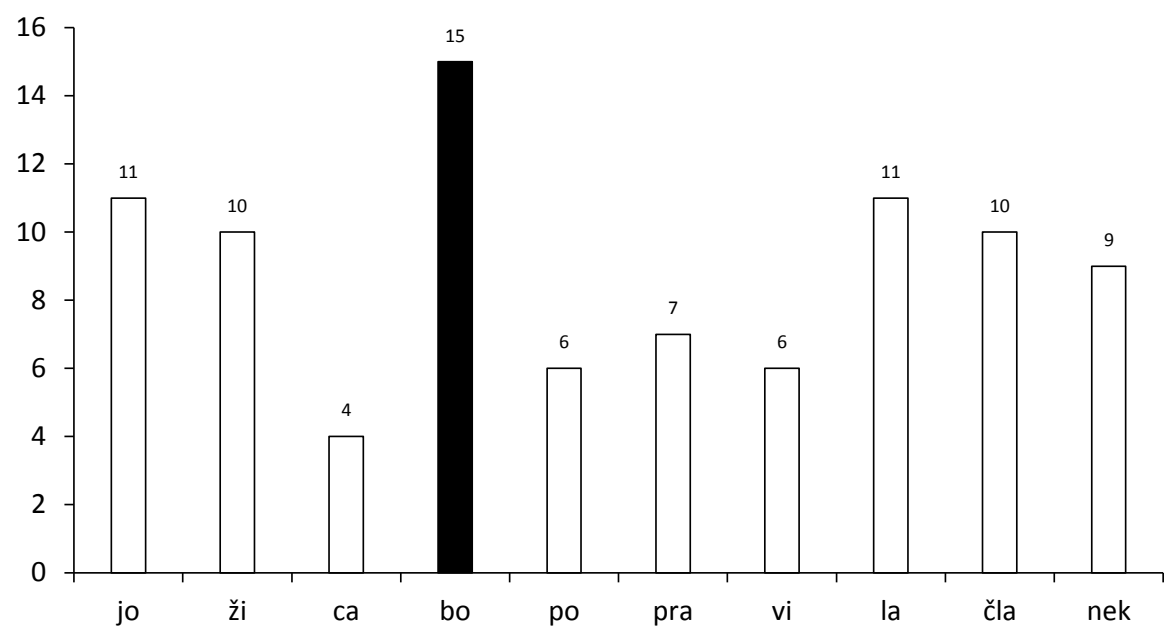

Figure 14: Syllable duration (in msec) in a sentence with verum focus

7 The second pitch jump (to the right of the one marked by an arrow) should be disregarded, as it due to segmental effects, i.e. it is caused by the voiceless consonant in the subsequent syllable. 
As established for previous focus types, the syllable with the focus exponent in the sentences with the verum focus is the longest syllable in the utterance. Figure 14 illustrates the duration of syllables in the utterance with the maximal non-contrastive focus; the focus exponent is marked in black (for the $\mathrm{F}_{0}$ contour of the same speaker $c f$. Figure 12).

\section{DISCUSSION}

The utterances included in the experiment were placed in pragmatic contexts that required the speakers to signal the IS by the appropriate placement and duration of sentence accents, and by the application of different pitch changes. The findings of the experiment support the approaches that observe a mapping between the syntactic and prosodic features of IS.

The pitch contours of utterances with non-contrastive focus exhibit an overall down-trending pattern. Regardless of the scope (maximal, intermediate or minimal), the syllable carrying the focus exponent falls on the final lexical item and is typically preceded by a falling pitch, which is then followed by a rise-fall of the $\mathrm{F}_{0}$ on the focus exponent. Out of context, the Slovenian sentences with maximal, intermediate or minimal focus scope are ambiguous; this finding is in line with the claims about focus scope in English (Ladd 1996: 202; Wells 206: 117).

The slight rise-fall on the non-contrastive focus exponent can be interpreted as the result of Slovenian tonemicity, which is in line with the findings of Toporišič (2004: 547-552), Srebot Rejec (1997: 429-430) and Šuštaršič (2005: 52) for Slovenian declarative sentences. The rising/acute (phonemic) tone on the stressed vowel is typically produced by speakers of the Upper and Lower Carniolan dialects, as well as speakers from the Slovenian capital, which includes the participants who read for the present experiment. It can be assumed that a similar rise in tone will not be produced by nontonemic speakers, resulting in an overall falling tone on the non-contrastive focus exponent, i.e. a tone similar to the one identified by Zybatow and Mehlhorn (2000: 425) for Russian sentences with this type of focus. We can conclude that the tonemic pitch of the focus exponent in Slovenian utterances with non-contrastive focus resembles the one presented for English by Xu and Xu (2005: 170), while the pitch on the focus exponent of non-tonemic Slovenian speakers is surmised to resemble the falling pitch associated with corresponding utterances in Russian (Zybatow/Mehlhorn 2000).

The experimental data for sentences with the non-contrastive focus also shows that the focus exponent represents only one of the noticeable pitch jumps in the observed utterances. Since it is linearly at the end of the down-trending curve, the rise of the $F_{0}$ occurs in the lower part of the speakers' pitch range. However, the highest pitch in such utterances (in the $300 \mathrm{~Hz}$ range) is on the stressed syllable of the sentence-initial constituent (cf. Dobnikar 1996: n.p.) which represents the topic of the sentence.

Additionally, the data on the syllable duration reveals that the non-contrastive focus exponent is also the syllable with the longest duration in the utterance, which corresponds to the data on Russian ( $c f$. Zybatow/Mehlhorn 2000: 425).

The pitch contours of sentences with the contrastively focused constituents include a strong rise on the syllable bearing the focus accent. In the utterance with the 
sentence-initial focused constituent, the pitch falls before the focus exponent, then rises to the highest position in the utterance (about $300 \mathrm{~Hz}$ ), before it starts falling again. The same pattern (fall + rise-fall) can be identified in utterances with sentence-medial and sentence-final contrastive focus constituents, the difference being only in the extent of the detected pitch jumps: the closer the focus exponent is to the end of the (overall down-trending) utterance, the smaller the jump in the fundamental frequency.

The findings outlined above are mostly consistent with previous observations for Slovenian by Srebot Rejec (1997: 438-439). While the maximal pitch target of the contrastive focus exponent was measured as higher than the maximal pitches of noncontrasted elements, the beginning of the intonation contour on the sentence-initial contrastive focus exponent was not lower than that in the contour of a non-contrasted element. From a cross-linguistic perspective, the finding about the high pitch target is expected - similar claims have been made for English (Xu/Xu 2005: 167) and Russian (Zybatow/Mehlhorn 2000: 426-427).

Interestingly, the finding of the decreasing pitch ranges of focus exponents in different sentential positions also confirms the early observations of Bezlaj (1939) on the prosody of individual words observing the general constraints of sentence intonation.

An analysis of syllable duration revealed that the syllable bearing the contrastive focus exponent is also the longest syllable in the utterance, which also confirms the claims by Katz end Selkirik (2011: 794) presented in the introduction, and the findings of Zybatow and Mehlhorn (2000: 430) for Russian.

The intonation contours related to the verum focus are parallel to the contours of sentences with the contrastive focus. They undergo a pitch fall before the focus exponent, which is followed by a rise-fall on the accented syllable. Even though the verum focus exponent presented herein is sentence-medial, it reaches the high pitch range of the topicalized sentence-initial constituent.

The data on syllable duration also show the verum focus exponent as the longest syllable in the utterance.

\section{CONCLUSION}

The study explores the prosody of sentence constituents that bear IS features and measures their effect on the intonation contour of the utterance. The experimental part is centred on Slovenian, and the collected data is compared to that in studies on English and Russian.

The main conclusion is that prosody can be used to distinguish between various types of IS features, specifically the non-contrastive focus, contrastive focus, and verum focus. The three types of focus share an overall down-trending $F_{0}$, a fall of pitch before the focus exponent and a rise-fall on the focus exponent. The contours of non-contrastive focus exponents are gently sloping (associated with tonemicity), whereas the contours of contrastive focus exponents contain a sharp rise, followed by a similarly sharp fall. While the various scopes of non-contrastive focus give rise to ambiguity - i.e. they cannot be disambiguated without proper pragmatic context - the changes in the fundamental frequency can still be relied on to identify the various types 
of focus exponents, especially the contrastive focus with its characteristic extended pitch range. Additionally, the focus exponents are identifiable with respect to their lengthened duration.

The study thus links the syntactic assignment of IS features to the prosodic characteristics of an utterance, and confirms the relevance of prosody for the reconstruction of the IS. Since the experiment was limited to declarative sentences and mostly centred on different types of focus, further research warrants a continued and more extensive scrutiny of IS effects, especially with regard to the [TOP] feature and other sentence types.

\section{References}

ALTER, Kai/Uwe JUNGHANNS (2002) "Topic-Related Prosodic Patterns in Russian.” In: Peter Kosta, Jens Frasek (eds), Current Approaches to Formal Slavic Linguistics. Frankfurt am Main: Lang, 73-87.

BISKUP, Petr (2011) Adverbials and the Phase Model. Amsterdam/Philadelphia: John Benjamins Publishing Company.

BOERSMA, Paul (2001) "Praat, a system for doing phonetics by computer." Glot International 5/9-10, 341-345.

BOERSMA, Paul/WEENINK, David (2005) Praat, doing phonetics by computer. 4.3.12, http://www.praat.org/

BEZLAJ, Franc (1939) Oris slovenskega knjižnega izgovora. Ljubljana: Učiteljska tiskarna.

BREUL, Carsten (2004) Focus Structure in Generative Grammar, An integrated syntactic, semantic and intonational approach. Amsterdam, Philadelphia: John Benjamins Publishing Company. http://dx.doi.org/10.1075/la.68

CHOMSKY, Noam (1995) The Minimalist Program. Cambridge, Mass.: The MIT Press.

CHOMSKY, Noam (1998) Minimalist Inquiries: The Framework. MIT Occasional Papers in Linguistics 15. Cambridge, Mass.: The MIT Press.

DOBNIKAR, Aleš (1996) "Modeling segment intonation for Slovene TTS system." In: Fourth International Conference on Spoken Language, 1996, ICLSP 96, Proceedings, Vol. 3. http://dx.doi.org/10.1109/ICSLP.1996.607995

HALLIDAY, M. A. K. (1967) Intonation and grammar in British English. The Hague/ Paris: Mouton.

HEDBERG, Nancy/Juan M. SOSA (2008) "The Prosody of Topic and Focus in Spontaneous English Dialogue." In: Chungmin Lee/Matthew Gordon/Daniel Büring (eds), Topic and Focus, Cross-linguistic Perspectives on Meaning and Intonation. Dordrecht: Kluwer Academic Publishers, 101-120. http://dx.doi. org/10.1007/978-1-4020-4796-16 6

ILC, Gašper/Milena Milojević SHEPPARD(2002)“Verb movementand interrogatives." Linguistica 42/1, 161-176. http://dx.doi.org/10.4312/linguistica.42.1.161-176

KATZ, Jonah/Elisabeth SELKIRK (2011) "Contrastive focus vs. discourse-new: Evidence from phonetic prominence in English." Language 87/4, 771-816. http:// dx.doi.org/10.1353/lan.2011.0076 
KOMAR, Smiljana (2008) Communicative functions of intonation: English-Slovene contrastive analysis. Ljubljana: Znanstvenoraziskovalni inštitut Filozofske fakultete.

JUNGHANNS, Uwe (1997) "Features and Movement." In: Alexiadou, A. et al. (eds), ZAS Papers in Linguistics 9, 74-88.

JUNGHANNS, Uwe (2002) Informationsstrukturierung in slavischen Sprachen. Zur Rekonstruktion in einem syntax-zentrierten Modell der Grammatik, Habilitationsschrift. Leipzig: Philologischen Fakultät, Universität Leipzig, 1-65.

JUNGHANNS, Uwe (2003) "Fokussierungsstrategien in slavischen Sprachen." In: Peter Kosta/Joanna Blaszczak/Jens Frasek/Ljudmila Geist/Marcena Zygis (eds), Investigations into Formal Slavic Linguistics. Frankfurt am Main: Lang, 181-199.

JUNGHANNS, Uwe/Gerhild ZYBATOW (1997) "Syntax and Information Structure of Russian Clauses." In: E. W. Browne et al. (eds), Annual Workshop on Formal Approaches to Slavic Linguistics. The Cornell Meeting 1995. Ann Arbor: Michigan Slavic Publications, 289-319.

LADD, Bob (1996) Intonational Phonology. Cambridge: Cambridge University Press. RIZZI, Luigi (1997) “The Fine Structure of the Left Periphery.” In: L. Haegeman (ed.), Elements of Grammar. Handbook of Generative Syntax. Dordrecht: Kluwer Academic Publishers, 281-337.

ROOTH, Mats (1992) "A theory of focus interpretation." Natural Language Semantics 1/1, 75-116. http://dx.doi.org/10.1007/BF02342617

ROOTH, Mats (1996) "On the interface principles for intonational focus." In: Galloway Theresa/Justin Spence (eds), Proceedings of SALT 6, April 26-28. New Brunswick, NJ: Rutgers University, 202-226.

SREBOT REJEC, Tatjana (1997) "Nekaj o stavčni intonaciji v knjižni slovenščini." Slavistična revija 45/3-4, 429-455.

ŠUŠTARŠIČ, Rastislav (1995) "Pitch and tone in English and Slovene." Linguistica 35/2, 91-106.

ŠUŠTARŠIČ, Rastislav (2005) English-Slovene contrastive phonetic and phonemic analysis and its application in teaching English phonetics and phonology. Ljubljana: Znanstveni inštitut Filozofske fakultete.

TOPORIŠIČ, JOŽE (2004) Slovenska slovnica. Maribor: Obzorja.

VITEZ, Primož/Véronique AUBERGÉ (1995) "Intonation gesture of Slovene: First indications." In: José Manuel Pardo (ed.), Eurospeech 95: proceedings. European conference on speech communication and technology. Madrid: Universidad Politecnica, 2073-2076.

WELLS, J. C. (2006) English intonation, An Introduction. Cambridge: Cambridge University Press.

XU, Yi/Ching X. XU (2005) "Phonetic realization of focus in English declarative intonation." Journal of Phonetics 33, 159-197. http://dx.doi.org/10.1016/j. wocn.2004.11.001

ZYBATOW, Gerhild/Uwe JUNGHANNS (1998) “Topiks im Russischen.” Sprache \& Pragmatik 47, 1-57. 
ZYBATOW, Gerhild/Grit MEHLHORN (2000) "Experimental evidence for focus structure in Russian." In: Irina A. Sekerina/Tracy Holloway Hall (eds), [Formal] approaches to [Slavic] linguistics, The Philadelphia meeting 1999. Ann Arbor: Michigan Slavic Publications, 414-434.

\section{Abstract \\ THE PROSODY OF FOCUS: NON-CONTRASTIVE, CONTRASTIVE AND VERUM FOCUS IN SLOVENIAN, ENGLISH AND RUSSIAN}

The article presents an approach to information structure that marks focused or topicalized syntactic constituents with the features [FOC] and [тоР], and assumes that the assignment of these information structure features is reflected in prosody. The experimental study measures the fundamental frequency of various Slovenian sentences to identify the characteristic contours of the non-contrastive, contrastive, and verum focus. The findings are compared to those in studies on English and Russian. The results show that the most relevant prosodic characteristics of such structures are the pitch range, the pitch changes on the focus exponent, and the duration of the focus exponent.

Keywords: non-contrastive focus, contrastive focus, verum focus, information structure, information structure features, pitch contour, intonation

Povzetek

PROZODIJA FOKUSA: NEKONTRASTIVNI, KONTRASTIVNI IN GLAGOLSKI FOKUS V SLOVENŠČINI, ANGLEŠČINI IN RUŠČINI

Prispevek predstavi pristop k informacijski zgradbi, ki označi fokusirane ali topikalizirane skladenjske sestavnike z oznakama [FOC] in [TоP], in privzame, da se pripis teh informacijsko-zgradbenih oznak odraža $v$ prozodiji. Eksperimentalna študija izmeri tonski potek različnih slovenskih stavkov, da bi določila značilne intonacijske krivulje nekontrastivnega, kontrastivnega in glagolskega fokusa. Ugotovitve primerja $\mathrm{s}$ tistimi iz študij o angleščini in ruščini. Rezultati pokažejo, da so bistvene prozodične značilnosti takšnih zgradb različni tonski razponi, spremembe tona na fokusnem eksponentu in trajanje fokusnega eksponenta.

Ključne besede: nekontrastivni fokus, kontrastivni fokus, glagolski fokus, informacijska zgradba, oznake informacijske zgradbe, krivulja osnovnega tona, intonacija 